\title{
NILAI PERUSAHAAN: STUDI EMPIRIS FAKTOR-FAKTOR YANG MEMPENGARUHI
}

\author{
ARWINA KARMUDIANDRI \\ MERRY ADITA CHANDRA \\ Sekolah Tinggi IImu Ekonomi Trisakti, Jl. Kyai Tapa No. 22, Jakarta, Indonesia \\ arwina@stietrisakti.ac.id
}

\begin{abstract}
The purpose of this research is to analyze factors influencing firm value. The independen variable are investment opportunity, dividen policy, managerial ownership, financial leverage, profitability, firm size, board of indepedent commissioner, audit comittee. Population of this research is non-financial companies which are listed in Indonesia Stock Exchange from 2015 to 2017. The sample of this research are selected by using purposive sampling method, and 198 datas are taken. Data were analyzed using multiple regression method. The result of this research shows that financial leverage, profitability and board of independent commissioner have influence to firm value, whereas investment opportunity, dividen policy managerial ownership, firm size and audit comittee do not have influence to firm value.
\end{abstract}

Keywords : Firm value, investmernt opportunity, dividen policy, managerial ownership, financial leverage

Abstrak: Tujuan penelitian adalah untuk menganalisis faktor-faktor yang mempengaruhi nilai perusahaan. Variabel independen terdiri dari keputusan investasi, kebijakan dividen, kepemilikan manajerial, kebijakan hutang, profitabilitas, ukuran perusahaan, dewan komisaris independen dan komite audit. Populasi di penelitian ini yaitu perusahaan non-keuangan yang terdapat di Bursa Efek Indonesia periode 2015 hingga 2017. Sampel penelitian ini ditentukan dengan menggunakan metoda purposive sampling, dan diambil 198 data. Data di analisis dengan menggunakan metode regresi berganda. Hasil penelitian menunjukkan bahwa kebijakan hutang, profitabilitas dan dewan komiaris independen memiliki pengaruh terhadap nilai perusahaan, sedangkan keputusan investasi, kebijakan dividen, kepemilikan manajerial, ukuran perusahaan dan komite audit tidak memiliki pengaruh terhadap nilai perusahaan.

Kata Kunci: Nilai perusahaan, keputusan investasi, kebijakan dividen, kepemilikan manajerial, kebijakan hutang

\section{PENDAHULUAN}

Pertumbuhan perekonomian Indonesia, hampir semua perusahaan dalam bentuk meningkatkan bisnisnya mengadakan bermacam-macam usaha untuk mencukupi keperluan modal. Perusahaan dalam mencukupi keperluan modalnya, digunakan untuk meningkatkan kegiatan usaha perusahaan. Cara untuk perusahaan meningkatkan investasi yaitu memasarkan kepemilikan perusahaan ke publik atau yang disebut go public. Perusahaan berupaya untuk meningkatkan investasi perusahaan agar memenuhi maksud perusahaan yaitu jangka pendek dan jangka panjang dimana jangka peendek yaitu memperoleh laba atau keuntungan dan jangka panjangnya untuk 
mengoptimalkan nilai perusahaan. (Utama dan Fidiana 2016).

Munawaroh dan Priyadi (2014) menyatakan bahwa mengoptimalkan nilai perusahaan sama juga mengoptimalkan kemakmuran shareholders yang adalah suatu tujuan perusahaan. Nilai perusahaan adalah tanggapan shareholders terhadap perusahaan. Nilai perusahaan yang meningkat maka akan memperlihatkan pemiliknya akan sejahtera. Nilai perusahaan dapat dilihat dari harga sahamnya. Apabila harga saham meningkat akan membuat nilai perusahaan jugapun meningkat. Bila nilai perusahaan meningkat akan meyakinkan pasar bahwa perusahaan mempunyai usaha yang baik untuk saat ini maupun untuk masa yang akan datang (Munawaroh dan Priyadi 2014).

Penelitian ini merupakan pengembangan dari penelitian yang dilakukan oleh Siboni dan Pourali (2015). Tujuan penelitian ini adalah untuk menguji secara empiris apakah keputusan investasi, kebijakan dividen, kepemilikan manajerial, kebijakan hutang, profitabilitas, ukuran perusahaan, dewan komisaris independen dan komite audit berpengaruh terhadap nilai perusahaan.

\section{Keputusan Investasi}

Keputusan investasi diartikan seperti gabungan dari aset tetap yang dimiliki dengan opsi dalam penanaman modal di masa depan. Yang perusahaan lakukan dalam penanaman modalnya adalah penanaman modal dengan menggunakan aset. Penelitian Siboni dan Pourali (2015), Rizqia et al. (2013) dan Haruman (2007) menunjukkan bahwa keputusan investasi berpengaruh terhadap nilai perusahaan. Namun penelitian Rinnaya et al. (2016) memperlihatkan bahwa keputusan investasi tidak memiliki pengaruh dengan nilai perusahaan.

$\mathrm{H}_{1}$ : Keputusan investasi berpengaruh terhadap nilai perusahaan.

\section{Kebijakan Dividen}

Dividen adalah hasil dari keuntungan perusahaan yang dibayarkan atau dibagikan perusahaan kepada investornya. Yang menjadi sorotan dalam kebijakkan dividen adalah bagaimana perusahaan membagikan laba yang ada kepada investor (Faridah dan Kurnia 2016). Karena keuntungan atau laba dapat dialokasikan dengan dua cara yaitu membagikannya langsung ke investor atau menahannya untuk keberlangsungan hidup perusahaan. Penelitian Siboni dan Pourali (2015), Rachman (2016) dan Rizqia et al (2013), Faridah dan Kurnia (2016) mengungkapkan bahwa kebijakan dividen berpengaruh terhadap nilai perusahaan. Namun menurut Masrifa (2016), Sofyaningsih dan Hardiningsih (2011) serta Utama dan Fidiana (2016) menunjukan bahwa kebijakkan dividen tidak berpengaruh terhadap nilai perusahaan.

$\mathrm{H}_{2}$ : Kebijakan dividen berpengaruh terhadap nilai perusahaan.

\section{Kepemilikan Manejerial}

Christiawan dan Tarigan (2007) menyatakan bahwa kepemilikan manajerial adalah manajer tersebut sekaligus sebagai pemegang saham perusahaan. Keadaan ini ditunjukkan dengan besarnya persentase kepemilikan saham perusahaan oleh manajer. Penelitian Siboni dan Pourali (2015), Abukosim et al. (2014), Muktharuddin (2014), dan Rizqia et al. (2013), Fuzuli et al. (2013) memperlihatkan bahwa kepemilikkan manajerial memiliki pengaruh terhadap nilai perusahaan. Namun, menurut Marius dan Masri (2017), Rano dan Midiastuty (2011) serta Rasyid (2015) menunjukkan bahwa kepemilikkan manajerial tidak berpengaruh terhadap nilai perusahaan.

$\mathrm{H}_{3}$ : Kepemilikan manajerial berpengaruh terhadap nilai perusahaan. 


\section{Financial Leverage}

Utama dan Fidiana (2016) menyatakan bahwa kebijakan hutang adalah cara agar dapat melihat perusahaan untuk menutupi aset perusahaan menggunakan seberapa banyak hutang. Apabila hutang suatu perusahaan berlebih maka perusahaan terikat dengan hutang untuk menutupi asetnya. Tapi apabila hutang rendah maka perusahaan menggunakan uang sendiri dalam menutupi asetnya. Penelitian menurut Rachman (2016), Rizqia et al. (2013), Rudangga dan Sudiarta (2016), Sheikh dan Khan (2016) dan Utama dan Fidiana (2016) menunjukkan bahwa leverage berpengaruh terhadap nilai perusahaan. Penelitian yang dilakukan Siboni dan Pourali (2015), Timbuleng et al. (2015) dan Siahaan (2013) menunjukkan bahwa leverage tidak berpengaruh terhadap nilai perusahaan.

$\mathrm{H}_{4}$ : Financial leverage berpengaruh terhadap nilai perusahaan.

\section{Profitabilitas}

Munawaroh dan Priyadi (2014) menyatakan bahwa profitabilitas merupakan gambaran dari kinerja manajemen dalam mengelola perusahaan. Utama dan Fidiana (2016) menyatakan bahwa kemampuan memperoleh laba disini diartikan sebagaimana perusahaan dapat memanfaatkan asetnya dengan optimal untuk menghasilkan keuntungan. Penelitian yang dilakukan Siboni dan Pourali (2015), Rizqia et al. (2013), Munawaroh dan Priyadi (2014) menunjukkan bahwa profitabilitas berpengaruh terhadap nilai perusahaan. Namun, penelitian Sakti dan Nugroho (2012) menyatakan bahwa profitabilitas tidak berpengaruh terhadap nilai perusahaan.

$\mathrm{H}_{5}$ : Profitabilitas berpengaruh terhadap nilai perusahaan.

\section{Ukuran Perusahaan}

Darminto (2007) menyatakan bahwa total aset yang dimiliki perusahaan dapat menjadi tolak ukur untuk melihat besar kecilnya suatu perusahaan. Perusahaan akan cenderung menggunakan debt financing untuk membiayai perusahaan bila perusahaan memiliki total aset yang besar dan yang berarti juga ukuran perusahaan yang besar. Sedangkan penelitian yang dilakukan oleh Masrifa (2016), Rizqia et al. (2016), Rudangga dan Sudiarta (2016) serta Onasis dan Robin (2016) menunjukkan bahwa ukuran perusahaan berpengaruh terhadap nilai perusahaan. Namun, penelitian yang dilakukan Siboni dan Pourali (2015), penelitian Dewi dan Wirajaya (2013), Suffah dan Riduwan (2016) memperlihatkan bahwa ukuran perusahaan tidak memiliki pengaruh terhadap nilai perusahaan.

$\mathrm{H}_{6}$ : Ukuran perusahaan berpengaruh terhadap nilai perusahaan.

\section{Dewan Komisaris Independen}

Wulandari dan Budiartha (2014) menunjukkan bahwa komisaris independen mempunyai tugas untuk membuat kebijakan yang digunakan oleh perusahaan. Komisaris independen juga dapat mengkomunikasikan tujuan para pemegang saham kepada para manajer. Berdasarkan penelitian Rano dan Midiastuty (2011) serta Muryati dan Suardikha (2014) menunjukkan bahwa dewan komisaris berpengaruh terhadap nilai perusahaan. Namun, penelitian yang dilakukan oleh Debby et al. (2014), Muktharuddin et al. (2014) serta Wulandari dan Budiartha (2014) menunjukkan bahwa dewan komisaris tidak berpengaruh terhadap nilai perusahaan.

$\mathrm{H}_{7}$ : Dewan komisaris independen berpengaruh terhadap nilai perusahaan.

\section{Komite Audit}

Menurut Reviani dan Sudantoko (2012) menyatakan bahwa dewan komisaris membentuk suatu komite dimana komite ini mempunyai tugas yaitu membantu dewan komisaris dalam melakukan kontrol terhadap perusahaan. Untuk melaksanakan kewajiban dewan komisaris terkait dengan melakukan 
pengawasan di dalam perusahaan dan pelaporan keuangannya merupakan tanggung jawab komite. Menurut Marius dan Masri (2017), Onasis dan Robin (2016) menyatakan bahwa komite audit berpengaruh terhadap nilai perusahaan. Namun, berdasarkan penelitian yang dilakukan oleh Debby et al. (2014), Rano dan Midiastuty (2011), Siahaan (2013) serta Muktharudin et al. (2014) menunjukkan bahwa komite audit tidak berpengaruh terhadap nilai perusahaan.

$\mathrm{H}_{8} \quad$ Komite audit berpengaruh terhadap nilai perusahaan.

\section{METODE PENELITIAN}

Sampel perusahaan dipilih dengan metode purposive sampling. Hasil pemilihan sampel dapat dilihat pada Tabel 1 berikut ini:

Tabel 1 Prosedur Pemilihan Sampel

\begin{tabular}{|c|c|c|c|}
\hline No & Keterangan & Jumlah & Data \\
\hline 1 & $\begin{array}{l}\text { Perusahaan non-keuangan yang secara konsisten } \\
\text { terdaftar di Bursa Efek Indonesia selama periode } \\
\text { 2014-2017 }\end{array}$ & 413 & 1239 \\
\hline 2 & $\begin{array}{l}\text { Perusahaan non keuangan yang tahun buku tidak } \\
\text { berakhir pada tanggal } 31 \text { Desember }\end{array}$ & (7) & (21) \\
\hline 3 & $\begin{array}{l}\text { Perusahaan non-keuangan yang tidak menyajikan } \\
\text { laporan keuangan dalam satuan mata uang rupiah }\end{array}$ & (81) & (243) \\
\hline 4 & Perusahaan non-keuangan yang tidak memperoleh laba & (132) & (396) \\
\hline 5 & $\begin{array}{l}\text { Perusahaan non-keuangan yang tidak memiliki } \\
\text { kepemilikan managerial periode } 2015-2017\end{array}$ & (92) & (276) \\
\hline \multirow[t]{2}{*}{6} & $\begin{array}{l}\text { Perusahaan yang tidak membagikan dividen selama } \\
\text { periode } 2015-2017\end{array}$ & (35) & (105) \\
\hline & Jumlah sampel & 66 & 198 \\
\hline
\end{tabular}

\section{Sumber: Olaha data}

Harga saham dapat menggambarkan nilai perusahaan, sehingga calon penanam modal menggunakan nilai perusahaan untuk mempertimbangkan penanaman modal di suatu perusahaan (Pertiwi et al. 2016). Nilai perusahaan diukur menggunakan skala rasio Tobin's $Q$ yang diambil dari penelitian (Siboni dan Pourali 2015) dengan rumus sebagai berikut:

$$
\text { Tobin's } Q=\frac{\text { (Market value of shares }+ \text { Debt) }}{\text { (Book value of assets) }}
$$
pertimbangan tentang menanamkan modal saat ini untuk memperoleh laba dimasa depan. (Faridah dan Kurnia 2016). Keputusan invertasi diukur dengan menggunakan skala rasio yaitu Total Asset Growth (TAG). TAG adalah perkembangan aset perusahaan dari satu tahun ke tahun selanjutnya. TAG adalah alat untuk mengukur pertumbuhan investasi yang dilakukan oleh perusahaan melalui aset tetap (Rinnayah et al. 2016)

Keputusan investasi= $\frac{B V \text { of } F A \text { in the } C Y-B V \text { of } F A \text { in the } P Y}{B V \text { of assets in the previous year }}$

Dividen adalah keuntungan yang perusahaan bagikan kepada pemegang saham. Kebijakan dividen menyangkut tentang masalah penggunaan laba yang menjadi hak para pemegang saham (Faridah dan Kurnia 2016). Kebijakan dividen diukur dengan menggunakan skala rasio yang merujuk pada penelitian (Siboni dan Pourali 2015) dengan rumus sebagai berikut : 


$$
D P R=\frac{\text { Dividen per share }}{\text { Earnings per share }}
$$

Kepemilikan manajerial adalah situasi dimana manajer tersebut sekaligus sebagai pemegang saham perusahaan (Christiawan dan Tarigan 2007). Kepemilikan manajerial dapat dihitung menggunakan skala rasio yang diambil dari penelitian (Siboni dan Pourali 2015) dengan rumus sebagai berikut :

$$
\text { Mown }=\frac{\text { Number of owned shares }}{\text { Total published shares }}
$$

Financial Leverage digunakan untuk menilai bagaimana aset dapat dibiayai oleh hutang. Semakin tinggi hutang perusahaan maka perusahaan terikat dengan pinjaman luar untuk menanggung asetnya. (Utama dan Fidiana 2016). Dalam penelitian ini leverage diukur dengan skala rasio yang diambil dari penelitian (Siboni dan Pourali 2015) dengan rumus :

$$
D A R=\frac{\text { Total Debt }}{\text { Total Assets }}
$$

Profitabilitas diartikan sebagaimana perusahaan dapat memanfaatkan asetnya dengan optimal untuk memperoleh keuntungan (Utama dan Fidiana 2016). Profitabilitas dari penelitian ini diukur dengan menggunakan Return On Asset (ROA) yang berskala rasio sama seperti pengukuran yang dilakukan oleh Siboni dan Pourali (2015) dengan rumus :

$$
R O A=\frac{\text { Net Income }}{\text { Total Assets }}
$$

Ukuran perusahaan dapat dilihat dari jumlah aset dalam perusahaan. Perusahaan akan semakin mudah mendapatkan pendanaan bila skala perusahaan juga besar (Rudangga dan Suidarta 2016). Ukuran perusahaan diukur dengan skala rasio yang diambil dari penelitian (Siboni dan Pourali 2015) menggunakan rumus sebagai berikut :

Ukuran perusahaan $=\log$ (Total Asset)

$$
\text { Rano dan Midiastuty (2011) }
$$
menyatakan bahwa komisaris independen bersikap objektif dalam menjalankan tugasnya di suatu perusahaan. Oleh karena itu jumlah komisaris independen menjadi faktor yang diperhatikan oleh perusahaan. Dewan komisaris independen dapat diukur menggunakan skala rasio yang diambil dari penelitian (Debby et al. 2014) dengan rumus sebagai berikut :

Dewan komisaris independen $=\frac{\text { komisaris independen }}{\text { dewan komisaris }}$ Menurut Reviani dan Sudantoko (2012) menyatakan bahwa komite audit adalah komite yang dibentuk oleh dewan komisaris untuk melakukan tugas pengawasan pengelolaan perusahaan. Komite audit dapat diukur dapat diukur menggunakan skala yang diambil dari penelitian (Debby et al. 2014) dengan menggunakan rumus sebagai berikut :

Komite audit=jumlah anggota komite audit

\section{HASIL PENELITIAN}

Hasil statistik deskriptif serta hasil pengujian hipotesis penelitian disajikan pada tabel di bawah ini:

Tabel 2 Statistik Deskriptif

\begin{tabular}{cccccc}
\hline Variabel & N & Minimum & Maximum & Mean & $\begin{array}{c}\text { Std. } \\
\text { Deviation }\end{array}$ \\
\hline TOBINSQ & 198 & 0,50747 & 23,28575 & 2,03150 & 2,82128 \\
KI & 198 & $-0,64139$ & 0,40073 & 0,02957 & 0,07843 \\
DIVIDEN & 198 & 0,03890 & 1,32734 & 0,33584 & 0,21817 \\
KM & 198 & 0 & 0,57840 & 0,04307 & 0,09579 \\
FL & 198 & 0,07497 & 0,81972 & 0,45471 & 0,18524 \\
ROA & 198 & 0,00722 & 0,45788 & 0,07920 & 0,07832 \\
UP & 198 & 10,81360 & 14,47077 & 12,73524 & 0,74254
\end{tabular}




\begin{tabular}{cccccc} 
DKI & 198 & 0,16667 & 0,80000 & 0,39077 & 0,10829 \\
KA & 198 & 1 & 5 & 3,14646 & 0,58210 \\
\hline
\end{tabular}

Sumber: Pengolahan Data SPSS

Tabel 3 Hasil Pengujian Hipotesis

\begin{tabular}{lcc}
\hline \multicolumn{1}{c}{ Model } & B & Sig. \\
\hline (Constant) & $-4,03319$ & 0,046 \\
KEPUTUSAN_INVEST & $-0,27177$ & 0,853 \\
DIVIDEN & 0,68852 & 0,199 \\
KM & 2,01919 & 0,091 \\
FL & 3,13148 & 0,000 \\
ROA & 28,21072 & 0,000 \\
UP & 0,07588 & 0,670 \\
DKI & 3,86276 & 0,000 \\
KA & $-0,12060$ & 0,560 \\
\hline
\end{tabular}

Sumber: Pengolahan Data SPSS

Nilai sig. pada keputusan investasi sebesar 0,853 lebih besar dari alpha 0,05, sehingga dapat disimpulkan bahwa $\mathrm{Ha}_{1}$ tidak diterima, hal ini menunjukkan bahwa variabel keputusan investasi tidak berpengaruh terhadap nilai perusahaan.

Nilai sig. pada kebijakan dividen sebesar 0,199 lebih besar dari alpha 0,05, sehingga dapat disimpulkan bahwa $\mathrm{Ha}_{2}$ tidak diterima, hal ini menunjukkan bahwa variabel kebijakan dividen tidak berpengaruh terhadap nilai perusahaan.

Nilai sig. pada kepemilikan manajerial sebesar 0,091 lebih besar dari alpha 0,05, sehingga dapat disimpulkan bahwa $\mathrm{Ha}_{3}$ tidak diterima, hal ini menunjukkan bahwa variabel kepemilikan manajerial tidak berpengaruh terhadap nilai perusahaan.

Nilai sig. pada financial leverage sebesar 0,000 lebih kecil dari alpha 0,05, sehingga dapat disimpulkan bahwa $\mathrm{Ha}_{4}$ diterima, hal ini menunjukkan bahwa variabel financial leverage memiliki pengaruh terhadap nilai perusahaan. Tabel diatas memperlihatkan bahwa financial leverage berpengaruh positif dengan nilai perusahaan, hal ini karena penggunaan utang akan meningkatkan nilai perusahaan karena biaya bunga utang, biaya bunga utang adalah biaya yang mengurangi pembayaran pajak sehingga akan menaikkan laba.

Nilai sig. pada profitabilitas sebesar 0,000 lebih kecil dari alpha 0,05, sehingga dapat disimpulkan bahwa $\mathrm{Ha}_{5}$ diterima, hal ini menunjukkan bahwa variabel profitabilitas berpengaruh terhadap nilai perusahaan. Tabel diatas menyajikan bahwa profitabilitas berpengaruh positif dengan nilai perusahaan, hal ini memiliki arti bahwa perusahaan efektif dalam melakukan operasionalnya hingga profitabilitas perusahaan meningkat.

Nilai sig. pada ukuran perusahaan sebesar 0,670 lebih besar dari alpha 0,05, sehingga dapat disimpulkan bahwa $\mathrm{Ha}_{6}$ tidak diterima, hal ini menunjukkan bahwa variabel ukuran perusahaan tidak berpengaruh terhadap nilai perusahaan.

Nilai sig. pada dewan komisaris independen sebesar 0,000 lebih kecil dari alpha 0,05, sehingga dapat disimpulkan bahwa $\mathrm{Ha}_{7}$ diterima, hal ini menunjukkan bahwa variabel dewan komisaris independen berpengaruh terhadap nilai perusahaan. Tabel diatas menyajikan bahwa komisaris independen 
berpengaruh positif dengan nilai perusahaan, maka semakin banyaknya dewan komisaris independen ini membuktikan bahwa dewan komisaris independen mampu menjalankan fungsi monitoring untuk mengawasi kebijakan serta kegiatan yang dilakukan oleh direksi.

Nilai sig. pada komite audit sebesar 0,560 lebih besar dari alpha 0,05, sehingga dapat disimpulkan bahwa $\mathrm{Ha}_{8}$ tidak diterima, hal ini menunjukkan bahwa variabel komite audit tidak berpengaruh terhadap nilai perusahaan.

\section{PENUTUP}

Hasil penelitian menunjukkan bahwa kebijakan hutang, profitabilitas dan dewan komiaris independen memiliki pengaruh terhadap nilai perusahaan, sedangkan keputusan investasi, kebijakan dividen, kepemilikan manajerial, ukuran perusahaan dan komite audit tidak memiliki pengaruh terhadap nilai perusahaan. Keterbatasan dari penelitian ini, yaitu (1) hanya menggunakan perusahaan non-keuangan yang terdaftar di Bursa Efek Indonesia (BEI), sehingga penelitian tidak dapat berlaku secara umum untuk negara selain Indonesia, (2) Penelitian ini hanya menggunakan 8 variabel independen untuk memprediksi nilai perusahaan, (3) periode yang digunakan dalam penelitian ini hanya 3 tahun, yaitu dari tahun 2015-2017. Rekomendasi untuk penelitian selanjutnya (1) Menggunakan perusahaan yang terdaftar pada Bursa Efek negara lain, (2) menambah variabel lain yang diprediksi menjadi faktor penentu nilai perusahaan, (3) periode penelitian bisa empat tahun atau lebih.

\section{REFERENCES:}

Abukosim, Mukhtaruddin, Ika Sasti Ferina, Claudya Nurcahaya. 2014. Ownership Structure And Firm Values: Empirical Study On Indonesia Manufacturing Listed Companies. Journal Of Arts, Science \& Commerce, $5,1-14$.

Christiawan, Yulius Jogi dan Josua Tarigan. 2007. Kepemilikan Manajeral:Kebijakan Hutang, Kinerja Dan Nilai Perusahaan. Jurnal Akuntansi Dan Keuangan, 9, 1-8.

Darminto. 2007. Factors Influencing Dividend Policy. Jurnal Administrasi Bisnis 1, 110-122.

Debby, Julia Farah, Mukhtaruddin, Emylia Yuniarti, Dewa Saputre, Abukosim. 2014. Good Corporate Governance, Company's Characteristics and Firm's Value: Empirical Study of Listed Banking on Indonesian Stock Exchange. GSTF Journal on Business Review (GBR), 3, 81-88.

Dewi, Ayu Sri Mahatma dan Ary Wirajaya. 2013. Pengaruh Stuktur Modal, Profitabilitas dan Ukuran Perusahaan pada Nilai Perusahaan. E-Jurnal Akuntansi Universitas Udayana, 4, 358-372.

Faridah, Nur dan Kurnia. 2016. Pengaruh Keputusan Investasi, Pendanaan, Kebijakan Dividen, Tingkat Suku Bunga Terhadap Nilai Perusahaan. Jurnal IImu Dan Riset Akuntansi, 5, 1-15.

Fuzuli, Muhammad Ilham, Indra Pahala, Yunika Murdayanti. 2013. The Influence Of Good Corporate Governance And Earnings Management On Firm Value. International Conference On Business And Economic Research, 4, 1-15.

Haruman, Tendi. 2007. Pengaruh Keputusan Keuangan dan Kepemilikan Institusional terhadap Nilai Perusahaan. National Coference On Management Research, 1, 1-20.

Marius, Maureen Erna dan Indah Masri. 2017. Pengaruh Good Corporate Governance Dan Corporate Social Responsibility Terhadap Nilai Perusahaan. Konferensi IImiah Akuntansi IV, 1-22.

Masrifa, Andyni Yulfanis Aulia. 2016. Karakteristik Perusahaan Terhadap Nilai Perusahaan, Dengan Dividend Payout Ratio Sebagai Variabel Intervening. Advance, 3, 1-19.

Mukhtaruddin, Relasari, M. Felmania. 2014. Good Corporate Governance Mechanism, Corporate Social Responsibility Disclosure on Firm Value: Empirical Study on Listed Company in Indonesia Stock Exchange. International Journal of Finance \& Accounting Studies, 2, 1-10. 
Munawaroh, Aisyatul dan Maswar Patuh Priyadi. 2014. Pengaruh Profitabilitas Terhadap Nilai Perusahaan Dengan Corporate Social Responsibilty Sebagai Variabel Moderating. Jurnal IImu \& Riset Akuntansi, 3, $1-17$.

Muryati, Ni Nyoman Tri Sariri dan I Made Sadha Suardikha. 2014. Pengaruh Corporate Governance pada Nilai Perusahaan. E-Jurnal Akuntansi Universitas Udayana, 9, 411-429.

Onasis, Kristie, dan Robin. 2016. Pengaruh Tata Kelola Perusahaan Terhadap Nilai Perusahaan Pada Perusahaan Keuangan yang Terdaftar di BEl. Bina Ekonomi, 20, 1-22.

Pertiwi, Putri Juwita, Parengkuan Tommy, Johan R. Tumiwa. 2016. Pengaruh Kebijakan Hutang, Keputusan Investasi dan Profitabilitas Terhadap Nilai Perusahaan Food and Beverages Yang Terdaftar di Bursa Efek Indonesia. Jurnal Riset Ekonomi, Manajemen, Bisnis, dan Akuntansi, 4, 1369-1380.

Rachman, Nur Aidha. 2016. Faktor-Faktor yang Mempengaruhi Nilai Perusahaan Pada Sektor Industri Food And Beverages Yang Terdaftar Di Bursa Efek Indonesia (Bei) Pada Tahun 2011-2015. Jurnal Pendidikan Dan Ekonomi, 5, 405-416.

Rano dan Pratana P. Midiastuty. 2011. Struktur Kepemilikan, Good Corporate Governance, Investasi Dan Nilai Perusahaan: Suatu Pengujian Sistempersamaan Simultan. Jurnal Akuntansi, 1, 40-66.

Rasyid, Abdul. 2015. Effects of ownership structure, capital structure, profitability and company's growth towards firm value. International Journal of Business and Management Invention, 4, 25-32.

Reviani, Dinni dan Djoko Sudantoko. 2012. Pengaruh Struktur Kepemilikan, Ukuran Perusahan, dan Corporate Governance Terhadap Manajemen Laba. Prestasi, 9, 92-108.

Rinnaya, Ista Yansi, Rita Andini dan Abrar Oemar. 2016. Pengaruh Profitabilitias, Rasio Aktivitas, Keputusan Pendanaan, Keputusan Investasi Terhadap Nilai Perusahaan. Journal of Accounting, 2, 1-18.

Rizqia, Dwita Ayu, Siti Aisjah dan Sumiati. 2013. Effect of Managerial Ownership, Financial Leverage, Profitability,Firm Size, And Investment Opportunity On Dividend Policy And Firm Value. Research Journal of Finance And Accounting, 4, 120-130.

Rudangga, I Gusti Ngurah Gede dan Gede Merta Sudiarta. 2016. Pengaruh Ukuran Perusahaan, Leverage, Dan Profitabilitas Terhadap Nilai Perusahaan. E-Jurnal Manajemen Unud, 5, 4394-4422.

Sakti, Kaharudinsyah Leon dan Penta Nugroho. 2012. Pengaruh Good Corporate Governance Terhadap Hubungan Antara Kinerja Keuangan dengan Nilai Perusahaan. Jurnal Manajemen, Akuntansi, dan Ekonomi Pembangunan, 10(2).

Sheikh, Nadeem Ahmed dan Muhammad Imran Khan. 2016. Effects of Excess Cash, Board Attributes and Insider Ownership on Firm Value: Evidence from Pakistan. Australasian Accounting, Business and Finance Journal, 10, 30-29.

Siahaan, Fadjar O.P. 2013. The Effect of Good Corporate Governance Mechanism, Leverage, and Firm Size on Firm Value. GSTF International Journal on Business Review (GBR), 2, 137-142.

Siboni, Zainab Morovvati, Mohammad Reza Pourali. 2015. The Relationship Between Investment Opportunity, Dividend Policy And Firm Value In Companies Listed In Tse: Evidence From Iran. European Online Journal Of Natural And Social Sciences, 4, 263-272.

Sofyaningsih, Sri, dan Pancawati Hardiningsih. 2011. Stuktur Kepemilikan, Kebijakan Dividen, Kebijakan Utang, dan Nilai Perusahaan. Dinamika Keuangan dan Perbankan, 3, 68-87.

Suffah, Roviqotus, Akhmad Riduwan. 2016. Pengaruh Profitabilitas, Leverage, Ukuran Perusahaan Dan Kebijakan Dividen Pada Nilai Perusahaan pengaruh Profitabilitas, Leverage, Ukuran Perusahaan Dan Kebijakan Dividen Pada Nilai Perusahaan. Jurnal IImu Dan Riset Akuntansi, 5, 1-17.

Timbuleng, Ferlen ,Sientje C. Nangoy dan Ivonne S. Saerang. 2015. Pengaruh Faktor Likuiditas, Leverage, Npm Dan Roi Terhadap Nilai Perusahaan. Jurnal Emba, 3, 546-557.

Utama, Yayak Ardy Pranata dan Fidiana. 2016. Pengaruh Kinerja Keuangan Terhadap Nilai Perusahaan Dengan Ukuran Perusahaan Sebagai Variabel Pemoderasi. Jurnal IImu dan Riset Akuntansi, 5, 1-18.

Wulandari, N. P. Yani dan I Ketut Budiartha. 2014. Pengaruh Struktur Kepemilikan, Komite Audit, Komisaris Independen dan Dewan Direksi Terhadap Integritas Laporan Keuangan. E-Jurnal Akuntansi Universitas Udayana, 7, 574-586. 